Chinas neue

Architektur 



\section{Christian Schittich}

\section{Chinas \\ neue \\ Architektur \\ Bauen im Kontext}

